\title{
本邦における脳ドック診療の知
}

\author{
菱川 朋人1)3)，伊達 勲1)3)，中瀬 裕之 ${ }^{2) 3)}$ \\ 1）岡山大学大学院医歯薬学総合研究科脳神経外科，2）奈良県立医科大学脳神経外科，3）日本脳神経外科学会
}

\section{Cutting-edge Knowledge of Brain Dock Practice in Japan}

\author{
Tomohito Hishikawa, M.D. ${ }^{1) 3)}$, Isao Date, M.D. ${ }^{1) 3}$, and Hiroyuki Nakase, M.D. ${ }^{2) 3(}$
}

1) Department of Neurological Surgery, Okayama University Graduate School of Medicine, Dentistry, and Pharmaceutical Sciences, 2) Department of Neurosurgery, Nara Medical School, 3) The Japan Neurosurgical Society

In this article, we discuss the history, current status, and features of brain dock practice in Japan. The brain dock system was introduced in Japan in 1988 and plays an important role in the field of preventive medicine. Based on a survey to determine the current status of brain dock evaluations performed in Japan, initiated by the Japan Neurosurgical Society, neurosurgeons are closely involved in brain dock practice. The first edition of the guidelines for brain dock application was published in 1997, and these guidelines are revised every 5 to 6 years. The aims of brain dock evaluation outlined in the revised fifth edition (2019) of the guidelines describe not only prevention of stroke but also prevention of cognitive impairment. Functional imaging and functional tests are recommended in addition to existing morphological imaging. Brain dock practice is entering a new era in Japan.

(Received August 24, 2020; accepted September 16, 2020)

Key words : brain dock, cognitive impairment, Japan, neurosurgeons, stroke

Jpn J Neurosurg (Tokyo) $30: 852-856,2021$

\section{はじめに}

脳ドックは本邦で始まった診療システムであり，主に 脳卒中を中心とした予防医学に大きな貢献をしてきた。 MRI などの画像機器の普及とその精度の向上, 超高齢化 社会の到来に伴い本邦の脳ドック診療も変革期にあると いえる。本稿では (一社) 日本脳神経外科学会が行った 「日本の脳ドックの現状と脳神経外科医の関与」に関する アンケート調査の結果を提示し, 脳ドック診療の歴史や 最近のトピックについて解説する.

\section{脳ドックの歴史}

1954 年に, 入院し健康診断を行ういわゆる「人間ドッ ク」が東京で初めて行われた。それから約 30 年の時を経 て 1988 年に札幌で未破裂脳動脈瘤を対象に脳血管撮影 によるスクリーニングが行われた。同じく 1988 年に島 根で無症候性脳梗塞を対象とした検診が行われ MRIを 用いてスクリーニングが行われた。この 1988 年の札幌 と島根での脳疾患に対する検診が本邦での脳ドック診療 の始まりといえる2．1992 年に日本脳ドック学会が設立 され，1997 年に脳ドックのガイドライン（初版）が発刊 されている。脳ドック診療の始まりから短期間で学会設 立，ガイドライン作成に至っていることから，本邦での 
脳ドック診療の重要性をうかがい知ることができる.

\section{脳ドックの現状}

日本脳ドック学会では施設認定指針として以下の基準 を設けている. (1)必須検査項目として問診, 診察, 血圧, 血液・尿・生化学検査, 心電図検査, 頭部 MRI 検査( $\mathrm{T} 1$, T2，FLAIR， T2 ${ }^{*}$ )，頭部 MRA 検査，頝部血管超音波検 査, 認知機能検査が実施されていること。また，推奨検 査として認知機能低下早期予測スコアが含まれること。 (2)脳ドック検査の説明指導では，画像検査の精度，読影 の適否ばかりでなく, 受診者への報告書に検査結果およ びその結果に基づき的確な指導が含まれていること4).

2018 年 12 月現在 288 施設が日本脳ドック学会認定施設 になっている。脳ドックのガイドラインは 1997 年に初 版が発刊され，以後 2003 年，2008 年，2014 年，2019 年 に改訂が行わ机 2019 年改訂第 5 版が最新のガイドライ ンになる。

2015 年に日本脳神経外科学会医療問題検討委員会に より「日本の脳ドックの現状と脳神経外科医の関与」と いうテーマでアンケート調査が行われた。2,013 施設(日 本脳ドック学会加盟 615 施設, 日本人間ドック学会加盟 1,638 施設）にアンケート用紙を送付し，606 施設から回 答を得た（回答率 $30 \%$ )。以下に主な質問とその結果を 示す.

\section{1. 脳ドックの実施形態}

脳ドック単独 $370 / 606$ 施設（61\%）

人間ドックや他の健診のオプション $378 / 606$ 施設 (62\%)

\section{2. 学会への届け出}

脳ドック学会認定 $28 \%$

脳ドック学会実施施設登録済（認定未） $9 \%$

脳ドック学会実施施設登録未 $63 \%$

\section{3. 脳ドックのガイドラインの利用}

ガイドラインを利用している $83 \%$

ガイドラインを利用していない $8 \%$

未回答 $9 \%$

\section{MRIの保有台数（Fig. 1)}

MRI を保有していない施設が $10 \%$ 存在するがこれら の施設では CT で代用していると思われる。

\section{MRIの磁場強度}

3 T $20 \%, 1.5 \mathrm{~T} 75 \%, 1.5 \mathrm{~T}$ 未満 5\%

\section{MRI の撮像内容}

$\mathrm{T} 1$ 強調画像 $67 \%$ ，T2 強調画像 $72 \%$, FLAIR 画像 $71 \%, \mathrm{~T} 2$ * 強調画像 51\%，プロトン強調画像 9\%, MRA

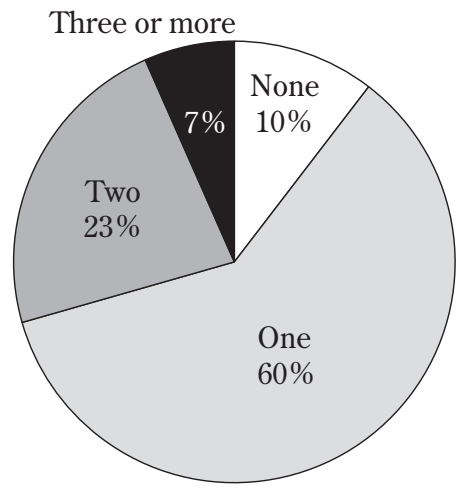

Fig. 1 Pie chart showing the number of facilityowned MRI units at each center

MRI : magnetic resonance imaging

元画像 $64 \%$

\section{7. 検査必須項目}

問診 $83 \%$ ，診察 $68 \% ，$ 血液検査 $64 \%$ ，心電図 $57 \%$, 頭部 MRI 84\%, 頭部 MRA 84\%, 頝部 MRA 46\%, 頝部 血管超音波検査 $46 \%$ ，認知機能検査 $29 \%$

\section{8. 画像読影を行う医師（Fig. 2)}

読影の中心は脳神経外科医，放射線科医であり，ほと んどの施設で脳神経内科医は読影を行っていない.

9. 脳ドック診療に関与する脳神経外科医の人数 (Fig. 3)

約 $2 / 3$ の施設で脳神経外科医は脳ドック診療に関わつ ている。

10. 脳ドック診療に関与する脳神経外科医の年齢分 布 (Fig. 4)

50 歳代が最多で 40 歳代，60 歳代，30 歳代の順でこれ に続く.

11. 脳ドック診療において脳神経外科医に期待する こと（自由意見）

・脳ドックによって脳動脈瘤や血管狭窄などを早期に 発見し治療につなげてほしい

・全身疾患（特に生活習慣病）に詳しくなってほしい

・認知症，変性疾患など手術に直接関係ない疾患に対 する知識を常にアップデートしてほしい

\section{脳ドックのトピック}

脳ドックのガイドライン 2019 には日本脳ドック学会 について,「脳卒中・認知症予防のための医学会」という サブタイトルが付けられている。これは脳ドックの役割 が今までの脳卒中予防のみならず認知症予防がもう $1 つ$ の大きな柱になることを意味する。これに伴い従来の形 


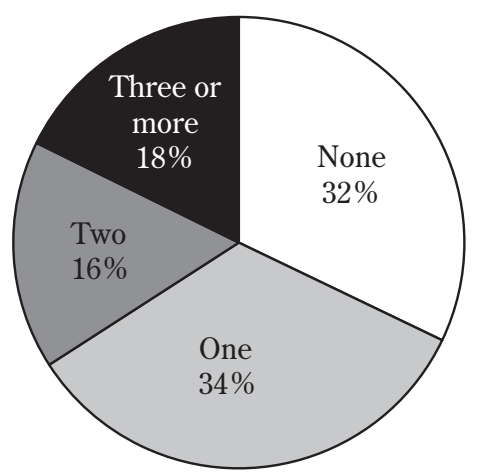

Neurosurgeon

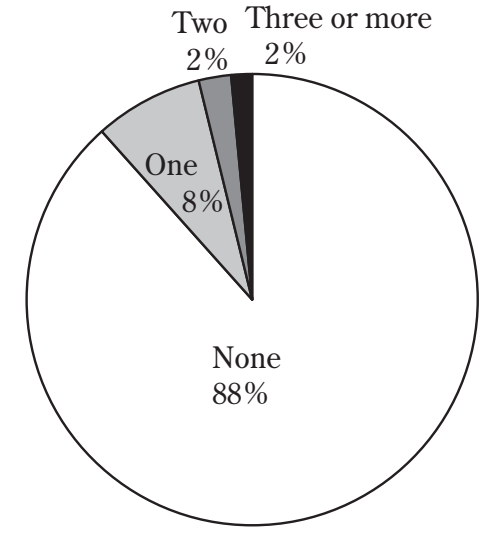

Neurologist

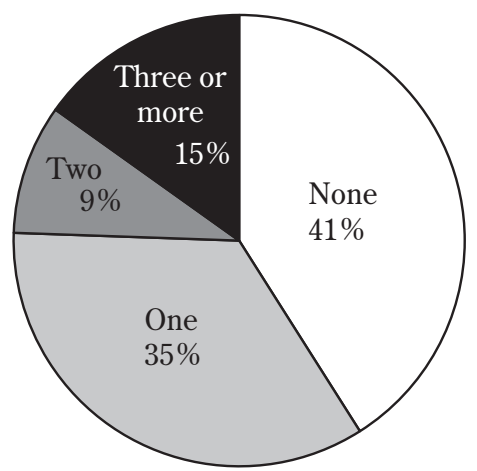

Radiologist

Fig. 2 Pie chart showing the number of neurosurgeons, neurologists, and radiologists involved with brain dock imaging evaluation at each facility

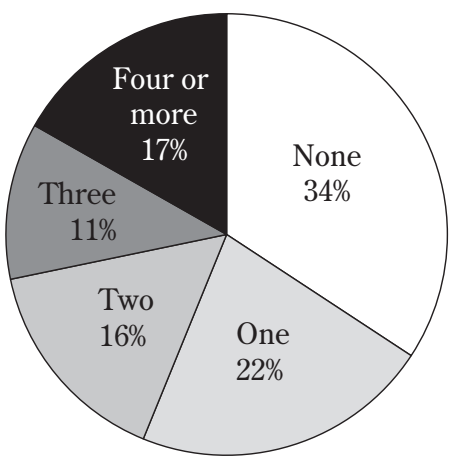

Fig. 3 Pie chart showing the number of neurosurgeons involved with the brain dock system at each facility

態画像のみならず機能画像や機能試験が重要となってく る. 形態画像の発展や最新の機能画像, 機能試験を紹介 する。

\section{Voxel-based morphometry}

灰白質の体積を定量化した形態画像の 1 つである。 T1 強調画像を基本としており，自動的に算出される。支援 ソフトして VSRAD（Voxel-Based Specific Regional Analysis System for Alzheimer's Disease) ${ }^{1}$ や BAAD (Brain Anatomical Analysis using Diffeomorphic Deformation $)^{6)}$ ある。認知症疾患診療ガイドライン 2017 には大脳萎縮 の局在に基づいた認知症の診断アプローチが紹介されて いる ${ }^{3)}$. 換言すれば大脳萎縮の客観的評価が重要であり voxel-based morphometry は認知症診断に有用なツール の1つと考えられる.VSRAD の代表症例を Fig. 5 に示 す。VSRADでは脳局所ごとの個々の患者の灰白質濃度

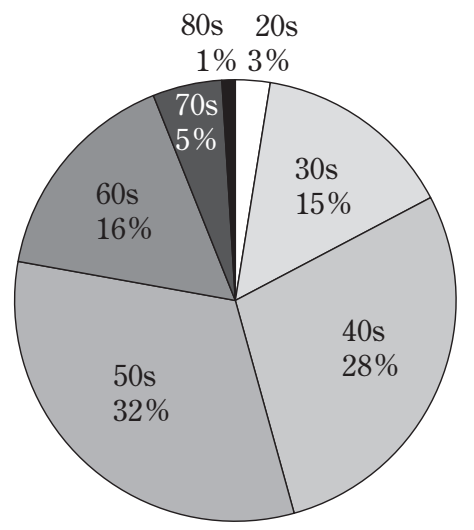

Fig. 4 Pie chart showing the age-wise distribution of neurosurgeons involved with brain dock practice 
A

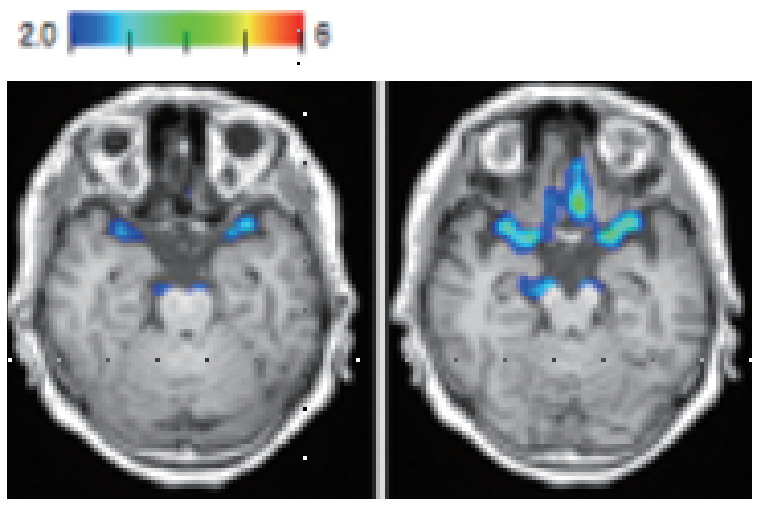

B

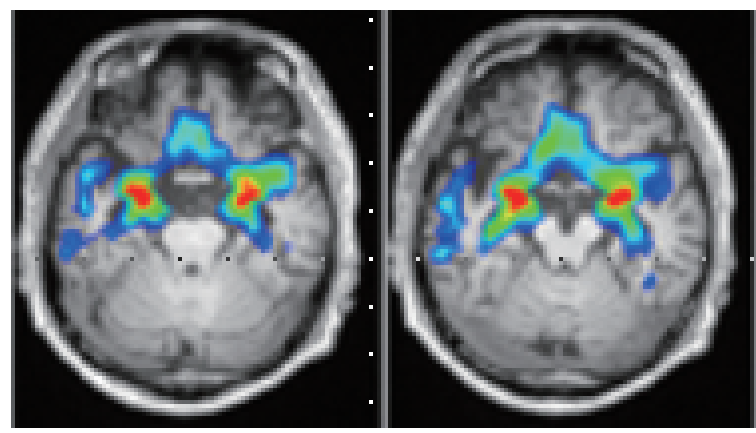

Fig. 5 Representative cases showing the use of VSRAD

A : A patient without Alzheimer's disease.

B : A patient with Alzheimer's disease.

Based on VSRAD evaluation, the degree of atrophy in the medial temporal regions is calculated as the ratio of 0.91 and 4.36 in $\mathbf{A}$ and $\mathbf{B}$, respectively.

VSRAD : voxel-based specific regional analysis system for Alzheimer's disease

Table 1 Early prediction score for cognitive decline ${ }^{4)}$

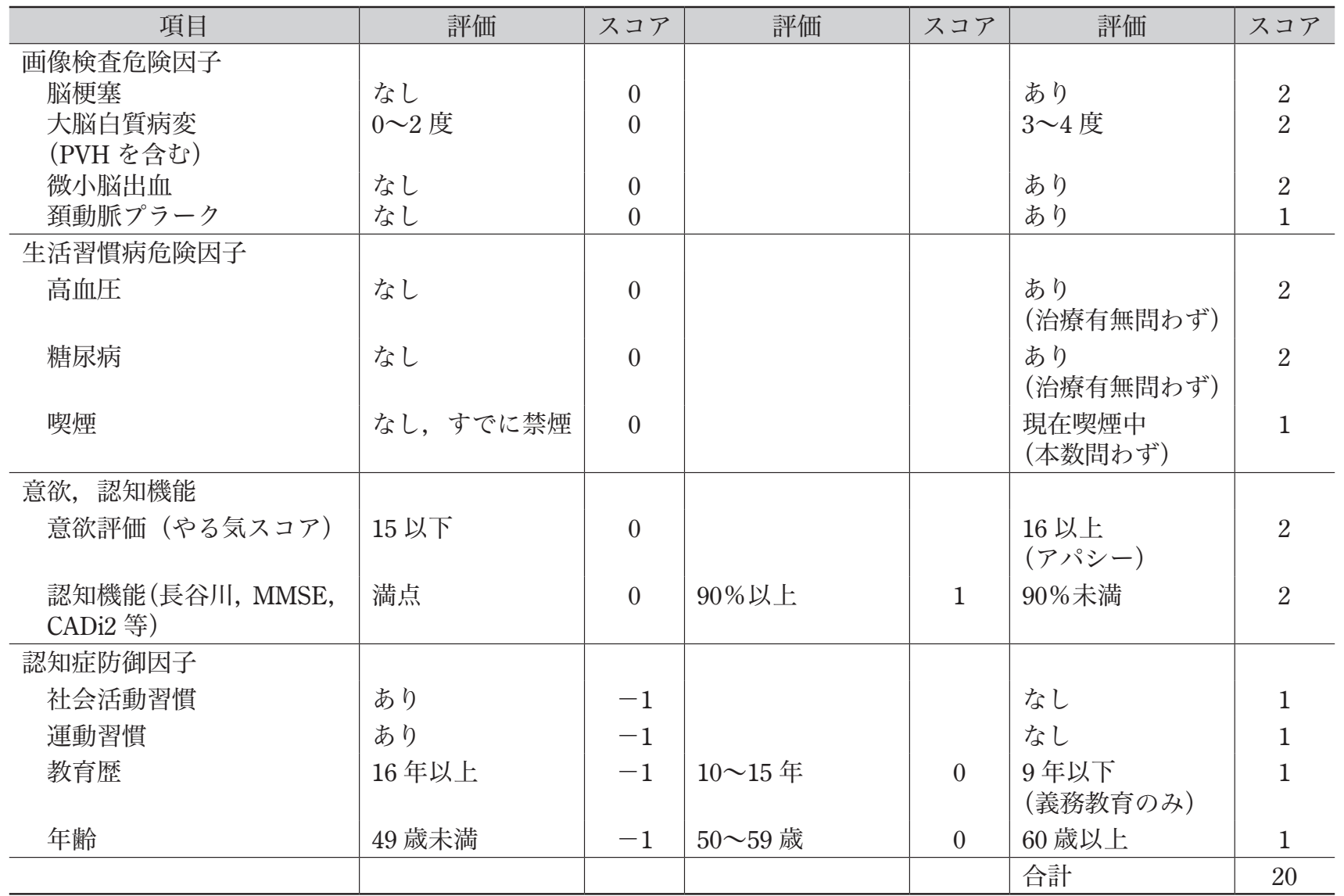

PVH : periventricular hyper-intensity, MMSE : Mini-Mental State Examination, CADi2 : Cognitive Assessment for Dementia, iPad version 2 


\section{3 機能試験（認知機能低下早期予測スコア）}

日本脳ドック学会認定施設指針に推奨検査として認知 機能低下早期予測スコアが揭げられている ${ }^{4)}$. 大規模長 期追跡研究や脳ドック追跡調査などをもとに作成された もので，画像検査因子，生活習慣病危険因子，意欲・認 知機能, 認知症防御因子から構成され, 各因子にスコア が割り振られ合計得点を算出し, 9 点以上は認知症の八 イリスクとされる（Table 1)。脳ドックでの活用が期待 されるツールである。

\section{おわりに}

本邦における脳ドック診療の歴史と現状をまとめ, 最 近のトピックを紹介した。本邦の脳ドックは世界に誇れ る診療システムであり, われわれ脳神経外科医は大きく 貢献している. 画像機器の進歩や時代の変革に伴い脳 ドック診療は新たな時代を迎えている，脳ドック診療を さらに充実したものにするために本稿が脳ドック診療の 知としてお役に立てれば幸いである。
COI

著者全員は日本脳神経外科学会への COI 自己申告の登録を 完了しています。

本論文に関して開示すべき COI はありません.

\section{文 献}

1) Hirata $Y$, Matsuda $H$, Nemoto $K$, Ohnishi T, Hirao K, Yamashita F, Asada T, Iwabuchi S, Samejima H : Voxelbased morphometry to discriminate early Alzheimer's disease from controls. Neurosci Lett $382: 269-274,2005$.

2）松田博史：認知症の CT/MRI一VSRAD を中心に一. $M B$ Med Rehab 132: 116-122, 2011.

3）日本神経学会監，「認知症疾患診療ガイドライン」作成委 員会編：認知症疾患診療ガイドライン 2017。東京，医学 書院, 2017.

4）脳ドックのガイドライン 2019 改訂委員会編: 脳ドックの ガイドライン 2019。札幌，響文社， 2019 .

5) Sheline YI, Raichle ME : Resting state functional connectivity in preclinical Alzheimer's disease. Biol Psychiatry $\quad \mathbf{7 4}$ : 340-347, 2013.

6）椎野顯彦，渡辺俊之，白樫義知，山田篤史，谷 徹，遠 山育夫：アルッハイマー病の VBM 解析に拈ける白質病 変の影響. Dementia Japan 28:339-347, 2014.

7）篠原幸人, 宮下正弘, 小林祥泰: 今月の問題点 鼎談: 人間ドックと脳ドック一両者の抱える問題点を中心に.

成人病と生活習慣病 45: 1039-1056, 2015.

本邦における脳ドック診療の知

\section{菱川 朋人 伊達 勲 中瀬 裕之}

脳ドック診療は 1988 年に本邦で始められた診療システムであり, 予防医学において重要な役割を 果たしてきた. 日本脳神経外科学会のアンケート調査において本邦では脳神経外科医が脳ドック診療 に深く関わっていることがわかった. 1997 年初版の脳ドックのガイドラインは計 5 回の改訂が行わ れている. 脳ドックのガイドライン 2019 では脳卒中・認知症予防のための医学会というサブタイト ルが付され, 脳卒中予防のみならず認知症予防も脳ドックの柱の1つとして据えられた.これに伴い 従来の形態画像だけでなく機能画像や機能検査が注目されている. 本邦の脳ドック診療は新たな時代 に入ったといえる. 